\title{
Navel Orangeworm (Lepidoptera: Pyralidae) Development in Sunburned Walnuts
}

\author{
MARK D. SHELTON AND DONALD W. DAVIS ${ }^{1}$ \\ Crop Science Department, Cal Poly State University, \\ San Luis Obispo, CA 93707
}

J. Econ. Entomol. 87(4): 1062-1069 (1994)

\begin{abstract}
Navel orangeworms, Amyelois transitella. (Walker), completed development in sunburned walnuts late in the growing season, but moths did not emerge until after harvest. Sunburned walnuts were not attractive to ovipositing moths until considerable hull damage occurred. Only sunburned walnuts with undamaged kernels were suitable for larval development. Navel orangeworm infestation levels up to $38 \%$ were recorded in sunburned walnut samples from the San Joaquin Valley, CA. Nut hull tissue damaged by sunburn was not selected over undamaged hull tissue for moth oviposition. Mean kernel temperatures of sunburned walnuts were higher than both undamaged walnuts and ambient air temperature. Premature hullsplit occurred in sunburned walnuts of both early and later maturity varieties. These data suggest that, although sunburned walnuts contribute to the seasonal buildup of navel orangeworms, the late development of navel orangeworms in these nuts reduces the incidence of infestation in hullsplit, new crop nuts.
\end{abstract}

KEY WORDS Amyelois transitella (Walker), navel orangeworm, sunburn

NAVEL ORANGEWORM, Amyelois transitella (Walker), is an important pest of almonds, Prunus amygdalus Batsch.; walnuts, Juglans regia Linn.; and pistachios, Pistacia vera Linn. in California. The lack of dependable chemical or biological controls for the navel orangeworm in walnuts has stimulated research on the field biology of this pest (Wade 1961, Falcon 1964, Bruce 1975, Sanderson et al. 1989). This insect is primarily a scavenger that breeds in at least 25 species of mummified fruits and nuts. It becomes a primary pest of nuts after hullsplit. Between three and five overlapping generations of navel orangeworm occur each year in California nut crops. The insect has no diapause and is active all year if conditions are favorable. Although numerous studies demonstrated the importance of walnuts damaged by walnut blight (Xanthomonas campestris pv juglandis) and codling moth, $C y$ dia pomonella (L.), as sites for navel orangeworm development, the role of sunburned walnuts in the pest's biology has been unknown.

Walnut sunburn results from high temperatures that darken and damage normally green hull tissue, usually on the upper nut surface. Early-leafing varieties, such as Ashley, Payne, and Serr, are susceptible to sunburn because they begin leaf senescence and hullsplit in $\mathrm{Au}$ gust, when air temperatures reach their peak in the interior California valleys (Shelton \& Ander-

\footnotetext{
1 Department of Biology, Utah State University, Logan, UT 84322-5305.
}

son 1990). Sunburn also is affected by orchard ground cover, irrigation method, tree vigor, aphid populations, and tree canopy size (Serr \& Foott 1963). Control of walnut aphid, Chromaphis juglandicola (Kaltenbach), and of Callaphis juglandis (Kaltenbach) helps prevent walnut sumburn. Both aphids excrete honeydew, which is phytotoxic to green hull tissue, turning hulls black and enhancing sunburn development (Sibbett et al. 1971). High aphid densities also cause leaf drop, increasing sunburn on exposed nuts. In our study, up to $35 \%$ of the walnut crop in commercial orchards was sunburned by August. Sunburn, and the resulting kernel shrivel and mold, is the single greatest cause of revenue loss to the walnut industry (G. Obenauf, Prune, Walnut and Raisin Research Board; Fresno, CA, unpublished data).

Sunburned walnuts may be susceptible to navel orangeworm attack when the hull tissue is sufficiently damaged to allow larval entry. Susceptibility of sunburned walnuts may precede that of undamaged nuts (Michelbacher \& Davis 1961). Kuenen \& Barnes (1981) determined that the hulls of undamaged almonds split sooner and faster in areas receiving greater radiant heat (i.e., the tree periphery, the southern exposure, and higher in the tree). Ortega (1950) and Michelbacher (1956) reported that sumburned walnuts were not attractive to navel orangeworms and played no important part in its ecology. Other authors reported sunburned walnuts as favoring navel orangeworm development, though no data 
on infestations in these nuts were published (Olson et al. 1975, Sibbett et al. 1987).

The objectives of our study were to determine the importance of sunburned walnuts as a site for navel orangeworm development and to clarify the phenology of sunburned nut infestation during the walnut growing season in the San Joaquin Valley, CA.

\section{Materials and Methods}

Field Infestation Levels. Weekly samples, each of 100 sunburned walnuts, were collected randomly from six commercial Payne and Ashley variety orchards in the San Joaquin Valley (one in the Sacramento Valley) during the 1985 and 1986 growing seasons. Sampled nuts were undamaged except for sunburned hulls, and only prehullsplit nuts were sampled. All nuts were clipped from limbs 2-4 m high, returned to a climate-controlled greenhouse, and maintained at a photoperiod of $16: 8$ (L:D) $\mathrm{h}$ to allow moth emergence. Nuts were placed individually into 7.5-cm-diameter styrofoam cups with organdy covers and held at fluctuating temperatures similar to those in sampled orchards $\left(10-34^{\circ} \mathrm{C}\right)$. Moth emergence from each nut was recorded twice weekly. After several months, all nuts were cracked open and inspected for navel orangeworm larvae and pupae. In 1987, weekly samples of 100 sunburned nuts were collected similarly in six orchards. Sampled sunburned nuts were treated as described. The orchards then were rated by percentage of sumburned nuts on 18 August. Five trees were selected randomly in each orchard and a 30-s visual count of sunburned nuts per tree was used to estimate the sunburned proportion of the crop. A walking survey of the entire orchard augmented the time count data. After several weeks, sampled nuts were cracked open and inspected for navel orangeworm larvae and pupae. Nut kernels were classified as moldy or shriveled ( $>1 / 4 \mathrm{kernel}$ volume) or were considered sound if free of defects. Differences in navel orangeworm infestation levels between walnut varieties and sample dates in 1985 were tested with chi-square analysis (Hoshmand 1988). Analysis of variance (ANOVA) was used to determine if significant differences in infestation levels existed because of sample date or variety in 1986 and because of sample date or walnut kernel condition in 1987. Differences among treatment means were analyzed with Duncan's (1955) multiple range test $(P=0.01)$.

Hullsplit Versus Sunburned Nut Infestation Levels. At season's end in 1986 and 1987, random samples of 100 each of hullsplit, sound, and sunburned walnuts were collected in Payne (Weiser) and Ashley (Clark) orchards (Merced County) to compare navel orangeworm infestation levels. Nuts were placed in the greenhouse and inspected three times weekly for moth emer- gence until December, when nuts were cracked, shelled, and inspected for larvae and pupae. Infestation levels of hullsplit and sunburned nuts were compared by chi-square tests.

Egg-Trap Monitoring. Navel orangeworm oviposition was monitored in a Payne (Crane) orchard (Merced County) and Serr (Christensen) orchard (Kings County) during the period of sunburn development in 1987. Four black navel orangeworm egg traps as described by Van Steenwyk \& Barnett (1985) were hung in each orchard on 1 June and inspected twice weekly until harvest. Egg-trap bait (almond presscake \& oil) was changed monthly to maintain trap attractiveness. Mean numbers of eggs per trap per day were plotted against cumulative degree-days and calendar date for each orchard. Degree-days were calculated by the single-sine curve method (Allen 1976); lower and upper developmental threshold temperatures were 12.8 and $34.4^{\circ} \mathrm{C}$, respectively, with a vertical upper cutoff (Sanderson et al. 1989).

Oviposition Phenology on Sunburned Walnuts. In 1988, a study was conducted to compare the timing of navel orangeworm oviposition on sunburned walnuts with that on sound, green walnuts. Groups of 100 randomly selected sunburned and green walnuts in the Christensen Hartley and Woods Ashley (Tulare County) orchards were tagged individually, then inspected for navel orangeworm eggs on 3 August and weekly thereafter until harvest. Neither orchard was sprayed during the study period. Egg location and number were recorded for each nut on each date. Differences in ovipositional timing and frequency between nut types were analyzed with chi-square statistics. ANOVA was used to determine if egg location on sunburned walnuts varied significantly. The progression of hullsplit among sunburned nuts observed for eggs was plotted against Julian date for each study orchard.

Artificial Infestation of Sunburned Walnuts. Two commercial walnut orchards near Gustine, CA, with a history of sunburn were selected for a 1986 study of navel orangeworm larval development in sunburned walnuts. The first study site was a mature orchard in Payne County (Weiser) bordered by a paved road to the south, where sunburn occurred. On 31 July, navel orangeworm egg sheets from the USDA Horticultural Crops Research Laboratory (Fresno, CA) colony were obtained and cut into pieces containing about 20 eggs each. Five randomly selected sunburned walnuts on each of 10 trees adjacent to the road were infested with navel orangeworm eggs on 1 August. A single egg sheet was attached to the sunburned portion of each nut with a 1-cm straight pin. Infested nuts were covered with nylon tulle bags $(50$ by $50 \mathrm{~cm}$ ) secured to the branch with a twist-tie to prevent feral navel orangeworm oviposition and to protect neonate 
larvae from predators. An equal number of sound nuts was infested similarly and bagged as a check on the experimental technique. A 31-d hygrothermograph was placed in the shade at the orchard to record air temperature. All bagged nuts were collected on 14 September (harvest) and returned to a climate-controlled greenhouse. Each nut was placed individually into a $7.5-\mathrm{cm}-$ diameter styrofoam cup with organdy cover and held at field temperatures for several months to allow larval and pupal development to continue. A hygrothermograph recorded greenhouse air temperature. Moth emergence was recorded twice weekly.

A similar experiment was conducted at a mature Ashley orchard (Clark) about $1 / 2 \mathrm{~km}$ east of the Weiser orchard. On 14 August, 50 randomly selected sunburned walnuts on 10 west-facing trees each were infested with about 202 -d-old navel orangeworm eggs from the USDA culture. Fifty sound nuts were infested similarly. All infested nuts were covered with nylon bags and handled as described. Differences in infestation and moth development levels between sound and sunburned walnuts were analyzed with chisquare tests.

In 1988, an experiment was conducted in the Woods Ashley orchard near Visalia, CA, to determine if only severely sunburned walnuts are susceptible to navel orangeworm infestation. On 27 July, 200 sunburned and 200 sound walnuts were selected randomly and inspected for navel orangeworm eggs. No eggs were found on any nuts or surrounding foliage. Fifty sunburned and 50 sound nuts each were infested with four neonate (<4-d-old) larvae collected from egg traps in walnut orchards in Hanford, CA. Nuts were rinsed with water, then a small droplet of honey was placed onto each nut near the petiole as a food source for the larvae. A dissecting probe dipped in water was used to place the larvae onto surface hull tissue of each nut. All infestations were done in the shade during early evening to allow larvae a better chance of survival. Infested nuts were covered with nylon tulle bags attached with twist-ties. The additional 150 sunburned and sound nuts originally inspected were bagged similarly to prevent feral moth oviposition. On 3 , 10, and 17 August, 50 sunburned and 50 sound nuts were unbagged and infested with neonate larvae as described. Each nut was inspected for feral navel orangeworms on each date before larval infestation. The trees with bagged nuts were unsprayed during the study period. Groups of 100 sunburned nuts were sampled randomly on each nut infestation date to compare feral infestation with that of the experiment. On 5 September, all bagged nuts were removed and dissected to determine infestation levels for each treatment date. Stage of larval development in infested nuts was determined using head-capsule measurements (Caltagirone et al. 1983). Chi- square analysis tested differences in nut infestation levels between sound and sunburned walnuts.

Walnut Temperature Measurements. Kernel temperatures of 100 sunburned and 100 green walnuts were measured on 24 August 1988 in a mature Payne orchard near Visalia, CA. All nuts were selected randomly at a $2-\mathrm{m}$ height in full sun exposure in a south-facing border row of trees. Ambient air temperature in a shaded tree canopy also was recorded. All temperatures were recorded with a Yellow Springs Instrument Model 43TA Tele-Thermometer (Yellow Springs, Ohio). A battery-powered hand drill was used to make a 3-mm-diameter hole into each nut to allow insertion of the temperature probe into the nut kernels. The probe was inserted about $1 \mathrm{~cm}$ into each nut and held in place until a stable temperature reading was made.

\section{Results and Discussion}

Field Infestation Levels. Navel orangeworm infested from 0 to $38 \%$ of sunburned walnuts sampled in 1985. Significantly higher infestation levels occurred in Payne walnuts $\left(X^{2}=6.83\right.$; $\left.\mathrm{df}=1 ; P>X^{2}<0.01\right)$ and in later sample dates for both varieties $X^{2}=38.4$; $\mathrm{df}=1 ; P>X^{2}<$ $0.01)$. One Payne walnut sample collected on 29 August produced numerous Habrobracon hebetor (Say), a larval parasite. Random samples of nonsunburned walnuts collected at three orchards on the later sample dates were not infested with navel orangeworm, probably because these larvae only enter damaged or hullsplit nuts.

Infestation and moth emergence data for sunburned walnuts collected in 1986 are shown in Table 1 . Neither walnut varieties $(F=2.62 ; \mathrm{df}=$ 3,14 ; MSE $=0.0035, P>0.05$ ) nor sample dates $(F=2.40 ; \mathrm{df}=2,15 ; \mathrm{MSE}=0.0038, P>0.05)$ differed significantly with respect to infestation level. Though generally higher infestation levels occurred in later samples, lower overall population levels at season's end and a high infestation in the first sample at the Basmajian orchard did not result in significant differences in infestation level due to variety and sample date. The mean percentage of infested nuts per sample in $\mathbf{1 9 8 5}$ was 8.0 and dropped to 4.0 in 1986. Also, the small number of sunburned nuts at the Basmajian orchard may have caused a concentrated oviposition on these nuts by the first sample because there were few codling moth- or blightdamaged walnuts to serve as alternate ovipositional sites. By the 26 August sample, hullsplit had occurred on many sunburned and sound walnuts (not sampled), which provided competing ovipositional sites for the few nonhullsplit sunburned nuts remaining. Emergence of moths from sampled nuts generally occurred after typical walnut harvest dates. Because nuts were 
Table 1. A. transitella infestation levels in sunburned walnuts, 1986

\begin{tabular}{|c|c|c|c|c|c|c|}
\hline Orchard & Variety & County & $\begin{array}{c}\text { Sample } \\
\text { date }\end{array}$ & $\begin{array}{l}\text { No. moths } \\
\text { emerged }\end{array}$ & $\begin{array}{c}\text { Emergence } \\
\text { period }\end{array}$ & $\begin{array}{l}\% \text { Nuts } \\
\text { infested }\end{array}$ \\
\hline \multirow[t]{3}{*}{ Christensen } & Serr & Kings & 4 Aug & 9 & 23 Sept-18 Nov & 4 \\
\hline & & & 14 Aug & 7 & 20 Sept-20 Oct & 3 \\
\hline & & & $18 \mathrm{Aug}$ & 112 & 4 Sept-20 Nov & 28 \\
\hline \multirow[t]{3}{*}{ Basmajian } & Vina & Kings & 4 Aug. & 12 & 23 Sept-24 Nov & 10 \\
\hline & & & 18 Aug & 4 & 3 Oct -20 Oct & 4 \\
\hline & & & $26 \mathrm{Aug}$ & 6 & $18 \mathrm{Sept}-20 \mathrm{Nov}$ & 8 \\
\hline \multirow[t]{3}{*}{ Clark } & Ashley & Merced & 15 Aug & 0 & - & 0 \\
\hline & & & 22 Aug & 4 & 3 Oct -6 Oct & 1 \\
\hline & & & 11 Sept & 11 & 7 Oct -20 Nov & 5 \\
\hline \multirow[t]{3}{*}{ Linville } & Payne & Merced & 5 Aug & 0 & - & 0 \\
\hline & & & $15 \mathrm{Aug}$ & 0 & - & 0 \\
\hline & & & 29 Aug & 4 & 23 Sept-18 Nov & 8 \\
\hline \multirow[t]{3}{*}{ Hamilton } & Ashley & Tulare & 4 Aug & 0 & - & 0 \\
\hline & & & 18 Aug & 1 & $15 \mathrm{Nov}$ & 1 \\
\hline & & & $26 \mathrm{Aug}$ & 7 & 15 Sept-15 Nov & 3 \\
\hline \multirow[t]{3}{*}{ Lang } & Ashley & Tulare & 4 Aug & 0 & - & 0 \\
\hline & & & 18 Aug & 5 & 24 Sept-26 Oct & 2 \\
\hline & & & 26 Aug & 1 & 24 Sept & 1 \\
\hline
\end{tabular}

held at fluctuating temperatures within the range of San Joaquin Valley temperatures, this emergence pattern indicates that navel orangeworm populations in sunburned walnuts fail to complete development in time to reinfest the newly hullsplit nuts.

Significant differences occurred in infestation level of sunburned walnuts as a result of sample date $(F=53.8 ; \mathrm{df}=4,20 ; \mathrm{MSE}=2.03, P<0.01)$ and nut kernel condition $(F=82.8$; df $=2,50$;
MSE $=2.92, P<0.01)$ in 1987 (Tables 2 and 3). Higher navel orangeworm infestation levels occurred on each subsequent sample date for nuts with sound kernels, though only the last three dates differed significantly. These results agree with the findings from 1985 and 1986 and indicate that sunburned walnuts are either unattractive to ovipositing moths or resistant to neonate larval penetration until late season because moths are common in walnut orchards through-

Table 2. A. transitella infestation levels in sunburned walnuts, 1987

\begin{tabular}{|c|c|c|c|c|c|c|}
\hline \multirow{2}{*}{ Orchard } & \multirow{2}{*}{$\begin{array}{l}\text { Variety } \\
\text { (county) }\end{array}$} & \multirow{2}{*}{$\begin{array}{c}\text { Sample } \\
\text { date }\end{array}$} & \multicolumn{3}{|c|}{ Kernel condition/no. infested nuts } & \multirow{2}{*}{$\begin{array}{c}\% \text { Infested } \\
\text { nuts }(n=100\end{array}$} \\
\hline & & & Sound & Moldy & Shriveled & \\
\hline \multirow[t]{5}{*}{ Tos } & Payne & 4 Aug & $59 / 0$ & $35 / 0$ & $6 / 0$ & 0 \\
\hline & (Kings) & $11 \mathrm{Aug}$ & $69 / 0$ & $25 / 0$ & $6 / 0$ & 0 \\
\hline & & $18 \mathrm{Aug}$ & $61 / 1$ & $31 / 0$ & $8 / 0$ & 1 \\
\hline & & 25 Aug & $53 / 10$ & $38 / 0$ & $9 / 0$ & 10 \\
\hline & & $8 \operatorname{Sept}^{a}$ & $86 / 23$ & $10 / 0$ & $4 / 0$ & 23 \\
\hline \multirow[t]{5}{*}{ Linville } & Payne & 4 Aug & $65 / 0$ & $31 / 0$ & $4 / 0$ & 0 \\
\hline & (Merced) & $11 \mathrm{Aug}$ & $55 / 0$ & $32 / 0$ & $13 / 0$ & 0 \\
\hline & & $18 \mathrm{Aug}$ & $62 / 3$ & $31 / 0$ & $7 / 0$ & 3 \\
\hline & & 25 Aug & $75 / 10$ & $11 / 0$ & $14 / 0$ & 10 \\
\hline & & $8 \mathrm{Sept}^{a}$ & $90 / 17$ & $5 / 0$ & $5 / 1$ & 18 \\
\hline \multirow[t]{5}{*}{ Clark } & Ashley & 4 Aug & $37 / 0$ & $52 / 0$ & $11 / 0$ & 0 \\
\hline & (Merced) & $11 \mathrm{Aug}$ & $49 / 1$ & $47 / 0$ & $4 / 0$ & 1 \\
\hline & & $18 \mathrm{Aug}$ & $83 / 0$ & $12 / 0$ & $5 / 0$ & 0 \\
\hline & & 25 Aug & $64 / 9$ & $21 / 0$ & $15 / 0$ & 9 \\
\hline & & $8 \mathrm{Sept}^{a}$ & $85 / 17$ & $8 / 0$ & $7 / 0$ & 17 \\
\hline \multirow[t]{5}{*}{ Crane } & Payne & 4 Aug & $71 / 0$ & $20 / 0$ & $9 / 0$ & 0 \\
\hline & (Merced) & $11 \mathrm{Aug}$ & $74 / 0$ & $23 / 0$ & $3 / 0$ & 0 \\
\hline & & $18 \mathrm{Aug}$ & $54 / 1$ & $36 / 0$ & $10 / 0$ & 1 \\
\hline & & $25 \mathrm{Aug}$ & $63 / 7$ & $25 / 0$ & $12 / 0$ & 7 \\
\hline & & $8 \mathrm{Sept}^{a}$ & $82 / 15$ & $6 / 0$ & $12 / 3$ & 18 \\
\hline \multirow[t]{5}{*}{ Christensen } & Serr & $4 \mathrm{Aug}$ & $67 / 0$ & $30 / 0$ & $3 / 0$ & 0 \\
\hline & (Kings) & $11 \mathrm{Aug}$ & $73 / 0$ & $19 / 0$ & $8 / 0$ & 0 \\
\hline & & $18 \mathrm{Aug}$ & $84 / 1$ & $10 / 0$ & $6 / 0$ & 1 \\
\hline & & 25 Aug & $50 / 6$ & $42 / 0$ & $8 / 0$ & 6 \\
\hline & & 8 Sept $^{a}$ & $76 / 20$ & $11 / 0$ & $13 / 0$ & 20 \\
\hline \multirow[t]{5}{*}{ Christensen } & Hartley & 4 Aug & $51 / 0$ & $37 / 0$ & $12 / 0$ & 0 \\
\hline & (Kings) & 11 Aug & $30 / 0$ & $55 / 0$ & $15 / 0$ & 0 \\
\hline & & $18 \mathrm{Aug}$ & $64 / 0$ & $22 / 0$ & $14 / 0$ & 0 \\
\hline & & $25 \mathrm{Aug}$ & $43 / 2$ & $41 / 0$ & $16 / 1$ & 3 \\
\hline & & 8 Sept $^{a}$ & $80 / 7$ & $9 / 0$ & $11 / 0$ & 7 \\
\hline
\end{tabular}

\footnotetext{
${ }^{a}$ After hullsplit.
} 
Table 3. Mean \pm SD sample date and kernel condition on $A$. transitella infestation in sunburned walnuts, 1987

\begin{tabular}{cccc}
\hline \hline \multirow{2}{*}{$\begin{array}{c}\text { Date } \\
\text { collected }\end{array}$} & \multicolumn{3}{c}{ Kernel condition } \\
\cline { 2 - 4 } & Sound & Moldy & Shriveled \\
\hline 4 Aug & $0.0 \pm 0.0 \mathrm{a}$ & $0.0 \pm 0.0 \mathrm{a}$ & $0.0 \pm 0.0 \mathrm{a}$ \\
$11 \mathrm{Aug}$ & $0.2 \pm 0.4 \mathrm{a}$ & $0.0 \pm 0.0 \mathrm{a}$ & $0.0 \pm 0.0 \mathrm{a}$ \\
$18 \mathrm{Aug}$ & $1.0 \pm 1.0 \mathrm{a}$ & $0.0 \pm 0.0 \mathrm{a}$ & $0.0 \pm 0.0 \mathrm{a}$ \\
$25 \mathrm{Aug}$ & $7.3 \pm 2.8 \mathrm{~b}$ & $0.0 \pm 0.0 \mathrm{a}$ & $0.2 \pm 0.4 \mathrm{a}$ \\
$8 \mathrm{Sept}$ & $16.5 \pm 4.9 \mathrm{c}$ & $0.0 \pm 0.0 \mathrm{a}$ & $0.7 \pm 1.1 \mathrm{a}$ \\
\hline
\end{tabular}

Data are means of six replicates; means in a row followed by the same letter do not differ significantly $(P>0.01)$.

out the period of sunburn damage. Studies of navel orangeworm development in almonds and pistachio indicated that oviposition on those nut crops commenced just prior to hullsplit (Beede et al. 1985). Because sunburn damage to hull tissue is progressive, later samples generally contained nuts with hull damage exceeding that of nuts in earlier samples. The final sample $(8$ September) consisted mainly of hullsplit sunburned nuts, which were infested heavily in all but the Hartley orchard. No significant differences in infestation levels over sample dates occurred in nuts with either moldy or shriveled kernels caused by low infestation levels in these nuts. Infestation levels differed significantly between nut kernel condition types over the last two sample dates. Navel orangeworm infestation levels among kernel condition types did not differ significantly in earlier samples because of low overall infestation levels. These data indicate that moths are more likely to oviposit on nuts with sound kernels than those with moldy or shriveled kernels and that navel orangeworm survival rates are much higher in nuts with sound kernels. Visual observation of each nut type does not describe kernel condition. Michelbacher \& Davis (1961) reported that walnuts without kernels seldom are infested by navel orangeworms, indicating either an ability of ovipositing moths to detect kernels inside nuts or the unsuitability of such nuts as developmental sites. Regardless of the mechanism by which moths select ovipositional sites, our results indicate that only nuts with essentially sound kernels are suitable developmental sites for navel orangeworms. Sound nuts comprised 30 to $90 \%$ of sunburned nuts sampled in 1987, with a mean of $65 \%$. Though significant differences in infestation levels existed between varieties in 1985 and 1987 , some variation was likely the result of regional differences in navel orangeworm populations and their management. All sampled orchards were in commercial production, and each was sprayed with an insecticide at least once during the growing season. The high navel orangeworm infestation levels in late-season sunburned walnuts indicated both the attractiveness of these nuts to the insect and the difficulty of managing this pest with current practices.

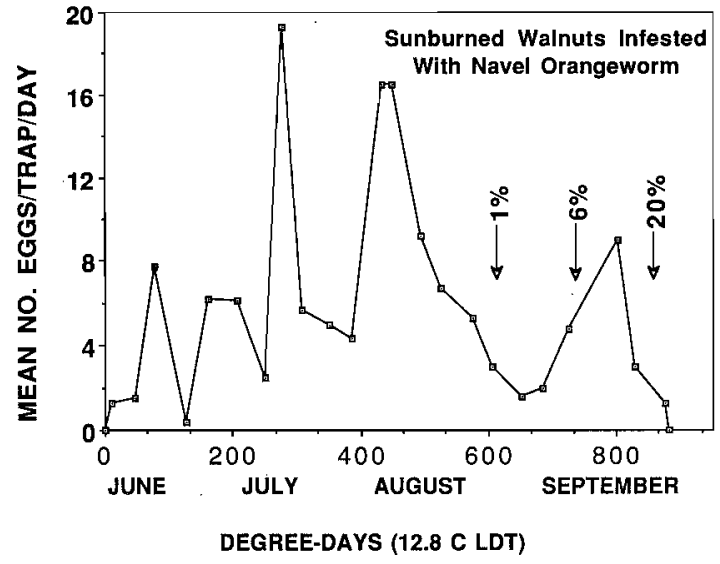

Fig. 1. Navel orangeworm egg-trap counts and degree-day accumulation, Christensen Serr orchard, 1987. LDT, lower developmental threshold.

Hullsplit Versus Sunburned Nut Infestation Levels. No significant differences in navel orangeworm infestation levels occurred between hullsplit, new crop walnuts, and sunburned walnuts $\left(X^{2}=0.192, \mathrm{df}=1\right)$. The similarity in infestation of hullsplit and sunburned walnuts indicates a lack of differential attractiveness to ovipositing moths between these substrata.

Egg-Trap Monitoring. Egg-trap data collected during the period of sunburn development show several major periods of oviposition before the collection of the first infested sunburned walnuts (Fig. 1-2). Peaks of egg-trap catch occurred in June, July, and August in both the Christensen (Serr) and Crane (Payne) orchards in 1987, despite two and three insecticide applications for navel orangeworm in these orchards, respectively. Although none of the samples of sunburned walnuts collected on 4 and 11 August were infested with navel orangeworms, which

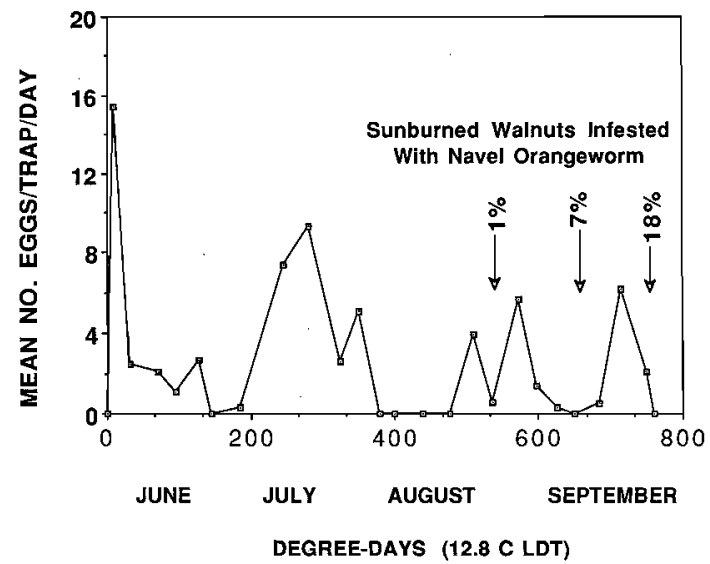

Fig. 2. Navel orangeworm egg-trap counts and degree-day accumulation, Crane Payne orchard, 1987. LDT, lower developmental threshold. 
Table 4. A. transitella oviposition on sunburned walnuts, 1988

\begin{tabular}{|c|c|c|c|c|c|c|c|c|}
\hline \multirow{3}{*}{$\begin{array}{l}\text { Observation } \\
\text { date }\end{array}$} & \multicolumn{4}{|c|}{$\%$ Sunburned walnuts with eggs } & \multicolumn{4}{|c|}{ No. eggs by location } \\
\hline & \multicolumn{2}{|c|}{ Nonhullsplit } & \multicolumn{2}{|c|}{ Hullsplit } & \multicolumn{2}{|c|}{ Green hull } & \multicolumn{2}{|c|}{ Black hull } \\
\hline & Hartley & $\overline{\text { Ashley }}$ & Hartley & $\overline{\text { Ashley }}$ & Hartley & Ashley & Hartley & Ashley \\
\hline 3 Aug & 0 & 0 & 0 & 0 & - & - & - & - \\
\hline $10 \mathrm{Aug}$ & 0 & 1 & 0 & 1 & - & 2 & - & 1 \\
\hline 17 Aug & 3 & 6 & 1 & 3 & 11 & 9 & 2 & 4 \\
\hline $24 \mathrm{Aug}$ & 7 & 5 & 4 & 5 & 8 & 7 & 5 & 7 \\
\hline $31 \mathrm{Aug}$ & 4 & 4 & 7 & 10 & 5 & 6 & 14 & 14 \\
\hline
\end{tabular}

were abundant in the Christensen orchard, these nuts likely were not suitable for insect development or were unattractive for oviposition. Competing ovipositional sites on these sample dates consisted of small numbers of walnuts damaged by codling moth (Christensen orchard) and a few mummy walnuts (both orchards). These ovipositional sites probably did not attract all ovipositing moths in each orchard, as indicated by the high egg-trap counts in the Christensen orchard.

Oviposition Phenology on Sunburned Walnuts. The seasonal pattern and location of navel orangeworm oviposition on sunburned walnuts in two commercial orchards is shown in Table 4. No eggs were laid on sound, green walnuts on any sample date in either orchard. Because navel orangeworm larvae are unable to penetrate undamaged walnut hulls, this finding suggests that moths select only suitable larval developmental sites for oviposition. Significant differences in percentage of sunburned walnuts with eggs occurred between sample dates $\left(X^{2}=21.1, \mathrm{df}=3\right.$, $\left.P>X^{2}<0.01\right)$. Later sample dates in both orchards had significantly more eggs per nut sample than earlier samples. This may explain the seasonality of infestation in sunburned nuts discussed and indicates that ovipositing moths select sunburned walnuts susceptible to larval attack (late season) rather than laying eggs on nuts unsuitable for infestation (early season). Egg levels per nut did not differ significantly between the varieties over sample dates, although leaves of Hartley trees grew 9-10 d after Ashley trees (Westwood 1978).

As oviposition progressed, hulls of numerous sunburned walnuts split prematurely. By $31 \mathrm{Au}^{-}$ gust, 37 of the original 100 Hartley and 41 of the Ashley nuts had at least partial hullsplit. Generally, minute cracks appeared first in blackened portions of the hull directly exposed to sunlight, although occasionally green hull tissue adjacent to blackened areas split. No green nuts showed any sign of hullsplit during the period of egg inspections. Premature hullsplit should make nuts more attractive to ovipositing moths. However, egg deposition on hullsplit versus nonhullsplit sunburned nuts did not differ significantly. Ovipositing moths likely do not favor a hullsplit sunburned walnut over a nonhullsplit sunburned nut, indicating both are suitable developmental sites.

Egg location on nuts did not differ significantly between the Hartley and Ashley orchards; thus, data for both orchards were pooled to compare numbers of eggs on black versus green hull tissue (Table 4). Hull tissue condition of sunburned walnuts did not differ significantly $(F=0.19$; $\mathrm{df}=1,2 ; \mathrm{MSE}=1.75 ; P>0.05$ ) for numbers of eggs laid.

Artificial Infestation of Sunburned Walnuts. Significantly higher levels of infestation $\left(X^{2}=\right.$ 180.7; $\left.\mathrm{df}=1 ; P>X^{2}<0.01\right)$ and subsequent moth development $\left(X^{2}=371.9 ; \mathrm{df}=1 ; P>X^{2}<\right.$ $0.01)$ occurred in artificially infested sunburned walnuts compared with sound walnuts. In 1986, less than $2 \%$ of sound nuts were infested, whereas sunburned nuts were 94 (Payne) and $98 \%$ (Ashley) infested. Twenty-five and $30 \%$ of navel orangeworm moths completed development in Payne and Ashley nuts, respectively. Differences were not significant for infestation and navel orangeworm development levels between orchards. These data show sunburned walnuts are suitable for navel orangeworm development. However, even with nut infestation on 31 July, moth emergence (greenhouse conditions) from infested nuts did not begin until well after harvest. Thus, navel orangeworm moths likely do not complete development in sunburned walnuts within a growing season and infest new crop walnuts. The data suggests they overwinter in unharvested sunburned mummies in trees or on the ground or are destroyed during postharvest nut processing.

Nut infestation dates and nut condition (sound versus sunburned) had significantly different navel orangeworm infestation levels in 1988 (Table 5). Significantly higher $\left(X^{2}=49.6 ; \mathrm{df}=3 ; P>\right.$ $\left.X^{2}<0.01\right)$ navel orangeworm infestation levels occurred in sunburned nuts that were infested artificially and field collected later in the season. This reflects the progressive hull damage and subsequent larval entry that occurs in sunburned walnuts over time. Sunburned nuts had significantly higher navel orangeworm infestation levels than undamaged nuts $\left(X^{2}=38.1 ; \mathrm{df}=1 ; P>\right.$ $\left.X^{2}<0.01\right)$. 
Table 5. A, transitella infestation levels in sound and sunburned walnuts after artificial infestation, 1988

\begin{tabular}{cccc}
\hline \hline $\begin{array}{c}\text { Infestation } \\
\text { date }\end{array}$ & \multicolumn{2}{c}{$\begin{array}{c}\text { Experimental } \\
\text { walnuts infested }\end{array}$} & $\begin{array}{c}\% \text { Field-collected } \\
\text { sunburned nuts } \\
\text { infested }^{a}\end{array}$ \\
\cline { 2 - 3 } & $\begin{array}{c}\text { Sound } \\
\text { nuts }\end{array}$ & $\begin{array}{c}\text { Sunburned } \\
\text { nuts }\end{array}$ & \\
\hline 27 July & 0 & 2 & 0 \\
3 Aug & 2 & 10 & 1 \\
10 Aug & 2 & 14 & 4 \\
17 Aug & 2 & 58 & 16 \\
\hline
\end{tabular}

${ }^{a}$ Random samples of 100 nuts collected on nut-infestation dates.

By 5 September, navel orangeworm larvae in infested sunburned walnuts ranged from second to sixth instar, with several pupae in nuts from the first two treatment dates. Of 39 total larvae found in 29 infested nuts from the 17 August infestations, 12 larvae were feeding on hull tissue and had not penetrated the nut shell. Fieldcollected sunburned nuts were infested with navel orangeworms in similar sequence as found in the artificial infestation experiments (Table 5).

Walnut Temperature Measurements. Ambientshade air temperature in the Payne orchard on 24 August at 1400 hours was $31.1^{\circ} \mathrm{C}$. Mean kernel temperatures for green and sunburned walnuts were 32.9 and $35.2^{\circ} \mathrm{C}$, respectively. The long period required for navel orangeworm development in sunburned walnuts may be explained partially by the high internal nut temperatures to which developing larvae and pupae are exposed. Shade air temperatures frequently exceed $31.1^{\circ} \mathrm{C}$ in walnut orchards in California valleys; yet, this air temperature caused a nut kernel temperature greater than the $34.4^{\circ} \mathrm{C}$ upper developmental threshold for navel orangeworm. It is likely, therefore, that navel orangeworm development in sunburned walnuts frequently is inhibited, resulting in an extended development time with some larval and pupal mortality. This prevents moths from emerging during the growing season, thus posing no threat to hullsplit, sound nuts unless harvest is delayed.

\section{Acknowledgments}

Navel orangeworm eggs for part of this research were supplied by Rodney Fries (USDA Horticultural Crops Research Laboratory, Fresno, CA). Thanks are extended to Lonnie Hendricks, Steve Sibbett, William Barnett, Dick Rice, Robert Van Steenwyk (University of California), John Sanderson (Cornell University), and Charles Curtis (USDA) for advice and technical assistance. We are grateful to Donald Sisson (Utah State University) for help in statistical analysis. This research was funded by grant no. 85 WMB 6 from the Walnut Marketing Board.

\section{References Cited}

Allen, J. C. 1976. A modified sine wave method for calculating degree days. Environ. Entomol. 5: 388396.

Beede, R. H., W. Bentley, R. E. Rice, L. S. Abelein, R. Cortez \& G. B. Weinberger. 1984-1985. Navel orangeworm management in pistachios. Calif. Pistachio Industry. Ann. Report, pp. 61-68. Calif. Pistachio Commission, Fresno, CA.

Bruce, D. L. 1975. Investigations on the management of insect and mite pests of walnuts in the central San Joaquin Valley of California, with emphasis on the control of the navel orangeworm, Paramyelois transitella (Walker). Ph.D. dissertation, University of California, Riverside.

Caltagirone, L. E., W. Getz \& D. W. Meals. 1983. Head capsule width as an index of age in larvae of navel orangeworm, Amyelois transitella (Lepidoptera: Pyralidae). Environ. Entomol. 12: 219-221.

Duncan, D. B. 1955. Multiple range and multiple $F$ tests. Biometrics. 11: 1-42.

Falcon, L. A. 1964. Factors affecting field populations of the navel orangeworm, Paramyelois transitella (Walker), on walnuts in northern California. Ph.D. dissertation, University of California, Berkeley.

Hoshmand, A. R. 1988. Statistical methods for agricultural sciences. Timber, Portland, OR.

Kuenen, L.P.S. \& M. M. Barnes. 1981. Spatial and temporal development of maturation of Nonpareil almonds and infestation by the navel orangeworm, Amyelois transitella (Walker). Environ. Entomol. 10: 673-675.

Michelbacher, A. E. 1956. Navel orangeworm on walnuts-infestation in northern California orchards dependent on population overwintering in past crop's waste left in field. Calif. Agric. 10: 8 .

Michelbacher, A. E. \& C. S. Davis. 1961. The navel orangeworm in northern California. J. Econ. Entomol. 54: 559-562.

Olson, W. H., L. C. Hendricks, G. S. Sibbett, C. S. Davis \& D. E. Ramos. 1975. Harvest timing and navel orangeworm. Diamond Walnut News 57: 8 .

Ortega, J. C. 1950. The navel orangeworm on walnuts in southern California. Diamond Walnut News. 32: 6.

Sanderson, J. P., M. M. Barnes \& W. S. Seaman. 1989. Synthesis and validation of a degree-day model for navel orangeworm (Lepidoptera: Pyralidae) development in California almond orchards. Environ. Entomol. 18: 612-617.

Seaman, W. S. \& M. M. Barnes. 1984. Thermal summation for the development of the navel orangeworm in almond (Lepidoptera: Pyralidae). Environ. Entomol. 13: 81-85.

Serr, E. F. \& J. H. Foott. 1963. Effects of whitewash cover sprays on Persian walnuts in California. Proc. of the Amer. Soc. of Hort. Sci. 82: 243-249.

Shelton, M. D. \& J. L. Anderson. 1990. Walnut cultivars: differential susceptibility to insect pests. Fruit Var. J. 44: 179-182.

Sibbett, G. S., C. S. Davis \& M. M. Barnes. 1971. Walnut aphid and the sunburn problem. Calif. Agric. 25: 12.

Sibbett, G. S., W. H. Olson, K. Kelley, W. W. Barnett \& R. Van Steenwyk. 1987. Management decision guide for walnuts. University of California, Divi- 
sion of Agriculture and Natural Resources. Oakland, CA.

Van Steenwyk, R. A. \& W. W. Barnett. 1985. Improvement of navel orangeworm (Lepidoptera: Pyralidae) egg traps. J. Econ. Entomol. 78: 282-286.

Wade, W. H. 1961. Biology of the navel orangeworm, Paramyelois transitella (Walker), on al- monds and walnuts in northern California. Hilgardia. 31: 129-171.

Westwood, M. N. 1978. Temperate-zone pomology. Freeman, San Francisco.

Received for publication 26 April 1993; accepted 21 March 1994. 